\title{
The Influence of Supply Chain Management on the Creative Economy Performance of the Culinary Sub-Sector During the COVID-19 Pandemic
}

\author{
Rian Ubaidillah \\ Master of Management Student \\ Mercu Buana University \\ Jakarta, Indonesia
}

\author{
Setyo Riyanto \\ Associate Professor \\ Mercu Buana University \\ Jakarta, Indonesia
}

\begin{abstract}
This research article advocates improving the performance of supply chain management (SCM) in the creative economy improvement industry in the culinary sub-sector during the COVID-19 pandemic. At present many businesses are struggling to replace the pandemic conditions, one of which is in business processes related to suppliers and distribution channels. Businesses are also required to have a competitive advantage for their businesses in order to maintain or increase the productivity of the creative culinary subsector during the COVID-19 pandemic. It will be the focus of the problem in this research article, which is to study the influence of supply chain management (SCM). It is supported by the results of data processing that shows the supplier variables (X3), distribution channels (X2), and competitive advantage (X1) on business performance $(Y)$ as the dependent variable. It reveals that special economic sector efforts in the culinary subsector need to be prepared strategies in dealing with the COVID-19 pandemic, specifically in supply chain management (SCM).
\end{abstract}

Keywords:- Competitive, Performance, Distribution Channel, Supplier, Supply Chain Management (SCM).

\section{INTRODUCTION}

The Head of the Ministry of Tourism's Culinary and Shopping Tourism Acceleration Development Team set criteria for Indonesian culinary destinations, including a firm commitment from the local government to develop culinary tourism potential, meet business, and hygienic aspects in its presentation (Sadiyah \& Putra, 2017).

Research conducted by UNWTO in 2012, recorded $87 \%$ of their respondents recognized that culinary is an essential element in travel. A culinary expert, William Wongso, also shares his views on food tourism trends. According to him, tourism activities that implement food tourism activities have been offered in many developed countries since 2000 (Pavitta et al. 2019).

However, now the world is facing a pandemic coronavirus (COVID-19), which has hampered the development of culinary tourism. Coronavirus 201 pandemic (COVID-19) is an infectious disease caused by COVID-19, which was only discovered in 2019. Most people infected with the coronavirus 2019 (COVID-19) will experience mild to moderate respiratory disease and recover without special treatment. However, for older people, and those who have fundamental medical problems such as cardiovascular disease, diabetes, chronic respiratory diseases, and cancer are more likely to develop serious illnesses (WHO, 2020).

When all countries were affected by the spread of COVID-19, including Indonesia, it became increasingly clear that COVID-19 was disrupting health and the economy. According to the International Monetary Fund (IMF) in the World Economic Outlook (2020), Indonesia's Gross Domestic Product (GDP) in 2019 is 5\%, and 2020 is estimated to be $0.5 \%$. It is due to the COVID-19 pandemic, but after this pandemic end, Indonesia is estimated to reach $8.2 \%$ in 2021 .

Governments around the world have implemented policies to limit activities, and social distance and are encouraged to stay at home to stop the spread of COVID-19. Consideration was taken in managing disease outbreaks in the world, as quoted from the public communication protocol in the context of co-19 (Ministry of Health, 2020).

The number of victims affected by pandemic diseases can be five times the actual number if there is fear during an outbreak. One thousand people became victims because of illness, and four thousand people became victims because of panic (Mello, 1997).

The Government of Indonesia through PP No.21 of 2020 concerning Large-Scale Social Restrictions in the Framework of Accelerating Handling of COVID-19. PP No.21 of 2020 has regulated and defined the definition of Large-Scale Social Restrictions (PSBB) is a limitation of specific activities for residents in an area suspected of being infected with coronavirus 2019 (COVID-19) in such a way as to prevent the possibility of its spread.

Moreover, based on DKI Governor Regulation No. 47 of 2020, which can apply for Exit Permit (SIKM) is intended for 11 sectors, including businesses engaged in the sector:

$>$ Restrictions on the movement of people and goods.

$>$ Freeing schools and workplaces.

$>$ Restrictions on religious activities.

$>$ Restrictions on activities in public places or facilities. 
Moreover, based on DKI Governor Regulation No. 47 of 2020, which can apply for Exit Permit (SIKM) is intended for 11 sectors, including businesses engaged in the sector:

$>$ Health.

$>$ Food / food / beverage ingredients.

$>$ Energy.

$>$ Communication and information technology.

$>$ Finance.

$>$ Logistics.

$>$ Hospitality.

$>$ Construction.

$>$ Strategic industries.

$>$ Essential services, public utilities, and

$>$ Industry determined as vital national objects and specific objects.

Moreover, it is currently coinciding with the occurrence of the COVID-19 pandemic. It is enough to make the wheels of the economy on various sides experience sluggishness, including the creative economy industry, especially in the culinary sub-sector. Culinary is a downstream product from the foodstuff/food/beverage sector. In government regulations that limit activities but also the needs of the community must still be met, this group has a high risk of losing income or being forced to work under harsh conditions. Many businesses, from suppliers and even stalls, reduce and close their businesses.

In order to remain productive, business actors need to find ways to remain earning and competitive amid the current COVID-19 pandemic. Therefore, the performance of culinary businesses can be measured by looking at relationships with suppliers, distribution channels, and competitive advantage. suppliers, distribution channels, and competitive advantages can be known as supply chain management. (Latifah \& Sham, 2020).

This article aims to analyze the influence of supply chain management on the performance of the creative economy industry, especially in the culinary sub-sector during the COVID-19 pandemic. So that will be the focus of the problem in this research article, namely, to determine the effect of suppliers, distribution channels, and competitive advantages on the performance of the creative economy industry with the culinary sub-sector during the COVID-19 pandemic.

Supply chain management is a process that cannot be released, namely, production activities from the raw materials obtained, the process of adding value that turns raw materials into finished materials, and the storage process to the process of sending consumer goods (Zulher \& Norawati, 2019).

The distribution channel chosen is the one that must be considered the most by business operators. With a proper distribution channel, the customer will be comfortable, and the business they have will be the choice. So that a proper distribution channel will improve business performance (Maychel \& Purnomo, 2020).
As cited in Setyawati (2015), Majeed said competitive advantage is significant and has an influence on improving business performance. Therefore, a competitive advantage is also needed by businesses to continue to struggle to face the COVID-19 epidemic.

\section{LITERATURE REVIEW}

\section{A. Creative Economy}

The creative economy has a vital role in these two decades and requires proper knowledge and skills to have a substantial economic impact. (OCED, 2014: 7).

The creative economy is closely related to the creative industry, but the creative economy has a broader scope than the creative industry. The creative economy is an ecosystem that has interdependent relationships between artistic value chains (creative value chain), development environment (nurturance environment), market (market), and archiving (archiving). The creative economy is not only related to the creation of added value economically, but also the creation of added value socially, culturally, and environmentally. Therefore, in addition to improving the creative economy, competitiveness can also improve the quality of life of the Indonesian people. (Indonesian Ministry of Tourism and Creative Economy: 2014).

In Indonesian Presidential Regulation Number 72 of 2015, concerning amendments to presidential regulation, number 6 of 2015 concerning creative economic bodies explains creative economic products classified into 16 subsectors which by the Central Statistics Agency (BPS) are then broken down into 206 Business Field Raw Classifications Indonesia (KBLI) 5 digits. Details of the sixteen consecutive creative economic subsectors according to the KBLI sequence are Architecture, Interior Design, Visual Communication Design, Product Design, Film, Animation, and Video, Photography, Craft, Culinary, Music, Fashion, Application and Game Developer, Publishing, Advertising, Television, and Radio, Performing Arts, Fine Arts (Bekraf, 2017).

Objectives The creative economy in Indonesia has been decided in Act 24 of 2019, aiming to optimize human resources' creativity based on cultural, scientific, and technological heritage. Creative economy and its potential need to be carried out in a systematic, structured, and sustainable management. The Creative economy has been protected by law in article 33 paragraph (4) of the 1945 Constitution of the Republic of Indonesia, with the aim that the Creative economy can have high competitiveness and be easily accessible. Its contents mandate that "The national economy is organized based on economic democracy with the principle of togetherness, fair efficiency, sustainable, environmentally friendly, independence, and maintaining the balance of progress and national economic unity (Jogloabang, 2019). 


\section{B. Supply Chain Management (SCM)}

Included in the Supply Chain Management Professional Board (CSCMP) defines supply chain management as: "Planning and management of all activities involved in procurement and procurement, conversion, and all logistics management activities. Importantly, this includes coordination and collaboration with channel partners, which can be suppliers, intermediaries, third-party service providers, and customers (Wisner et al., 2012).

Defined supply chain management has enhanced the concept of modern business management from domains that focus on organizations to systems that focus on supply chains, thereby increasing effectiveness in achieving strategic objectives. Today's competition is no longer seen as a company against a company but a supply chain against a supply chain. Therefore, supply chain management is a new perspective on old activities (Lu, 1998).

Activities in the supply chain are seen as functions such as purchasing, planning, scheduling, manufacturing, and distribution. Supply chain management (SCM), material flow, and information flow across traditional functional boundaries are seen as single processes. This flow is illustrated in the simplified model in Figure 1 (Basu \& Wright, 2008)

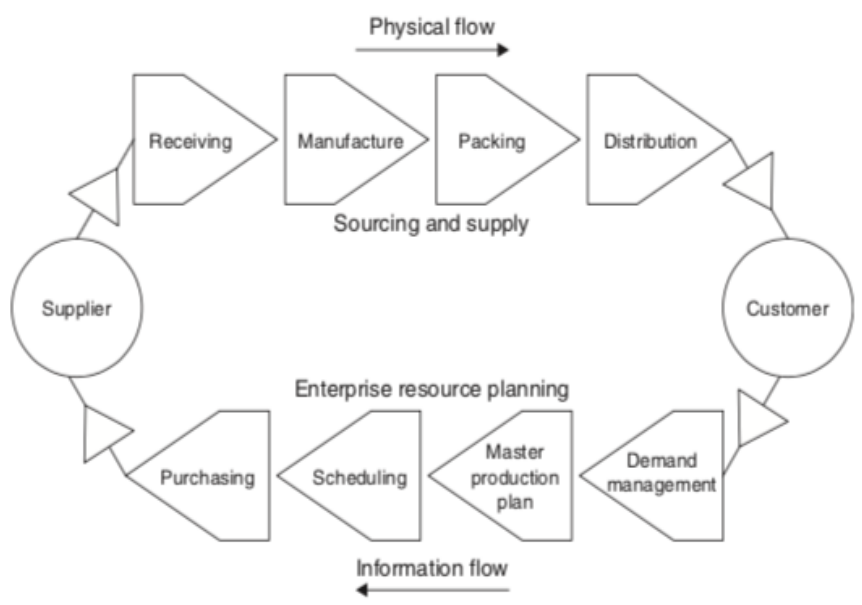

Fig 1:- Supply Chain Management (SCM)

\section{Supplier}

According to Chopra and Meindl (2013), supply chain management is the activity of managing all parts that handle customer demand either directly or indirectly. Supply chain management is the order of the organization, facilities, functions, and activities involved in the production and delivery of a product or service.

\section{Distribution Channel}

Channels for goods are distribution channels used by producers to distribute goods to consumers or industrial users (Swastha, 2007). So that distribution channels are essential in business. Therefore, businesses must determine strategies in the selection of distribution channels.
In general, distribution channels can be interpreted as a form of activity to facilitate and facilitate customers in getting goods or services needed from producers (Tjiptono, 2008).

\section{E. Competitive Advantage}

Competitive advantage is a set of factors that determine a company from the competition. The key to business success is the development of a unique competitive advantage that results in what is difficult for competitors to imitate and value for customers (Adiputra, 2017). The consistency of its members can obtain a competitive advantage (Riyanto \& Lukertina, 2019).

\section{F. Business Strategy}

Business Strategy is a strategy that reflects the entire direction of the business, intending to create growth for the business as a whole, and manage various types of product line businesses. There are three types of strategies that can be used in this company-level strategy; that is, a growth strategy is a strategy based on the level of growth that is being traversed by the company. Stability strategy is a strategy in facing the decline in income faced by a business. And the savings strategy is a strategy implemented to minimize or reduce the efforts made (Wheelen. 1995).

\section{METHODS}

In this research, a quantitative approach is used to explain the influence between supplier variables $\left(\mathrm{X}_{1}\right)$, distribution channels $\left(\mathrm{X}_{2}\right)$, and competitive advantage $\left(\mathrm{X}_{3}\right)$ on business performance (Y). The questionnaire was distributed to 56 respondents who were businesspeople in the creative industries with the culinary sub-sector. Data analysis techniques used are as follows:

Finally, complete content and organizational editing before formatting. Please take note of the following items when proofreading spelling and grammar:

\section{A. Validity Test}

A validity test is used to test which question items are valid and invalid (Maida, 2017). The validity test in this study was conducted by comparing the value of $r$ arithmetic with $r$ table. If the value of $r$ count is higher than $r$ table, then the questionnaire items are valid.

\section{B. Reliability Test}

The reliability test is used to find out the question items used are reliable as a measurement tool. The method used to measure the reliability of the questionnaire is by using Cronbach's Alpha method for each measured variable (Setiawan, 2016). Variables can be categorized as reliable if they have an alpha value higher than 0.60 (Riyanto, 2019).

\section{Multiple Linear Regression Analysis}

The reliability test is used to find out the question items used are reliable as a measurement tool. The method used to measure the reliability of the questionnaire is by using Cronbach's Alpha method for each measured variable 
(Setiawan, 2016). Variables can be categorized as reliable if they have an alpha value higher than 0.60 (Riyanto, 2019).

\section{Reliability Test}

This analysis is used to determine the direction of the relationship between the dependent and independent variables, whether each independent variable is positive or negative. This analysis predicts the value of the dependent variable when there is an increase or decrease in the independent variable (Maida, 2017). The form of the multiple linear regression equation used is as follows:

$$
\begin{array}{ll}
\mathbf{Y}=\mathbf{a}+ & \mathbf{b}_{\mathbf{1}} \mathbf{X}_{\mathbf{1}}+\mathbf{b}_{\mathbf{2}} \mathbf{X}_{\mathbf{2}}+\mathbf{b}_{\mathbf{3}} \mathbf{X}_{\mathbf{3}}+\mathbf{e} \\
\mathrm{Y} & =\text { Business Performance } \\
\mathrm{a} & =\text { Constant } \\
\mathrm{b}_{1} \ldots \mathrm{b}_{3} & =\text { Regression Coefficients } \\
\mathrm{X}_{1} & =\text { Supplier } \\
\mathrm{X}_{2} & =\text { Distribution Channel } \\
\mathrm{X}_{2} & =\text { Competitive Advantage } \\
\mathrm{e} & =\text { Error }
\end{array}
$$

\section{E. Descriptuve Analysis}

Descriptive analysis is used to analyze data by describing or describing data that has been collected so that the data presented can be easily understood and informative (Sholikhah, 2016). Descriptive hypotheses and statistical hypotheses can be arranged as follows.

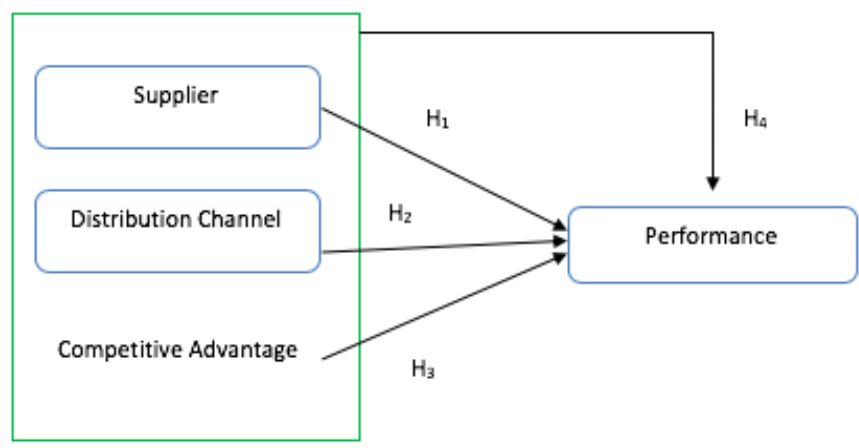

Fig 2:- Framework Model

Hypothesis

$\mathrm{H}_{1}$ : Suppliers influence business performance.

$\mathrm{H}_{2}$ : Distribution channels influence business performance.

$\mathrm{H}_{3}$ : Competitive advantage influence business performance

$\mathrm{H}_{4}$ : Suppliers, distribution channels and competitive advantage influence business performance.

\section{RESULT AND DISCUSSIONS}

Result and discussion contain the answers to the research problems and conclude explicitly. For qualitative research, this discussion contains research ideas, linkage between dimensions and the position of findings on previous findings and theories. This chapter contains the results of research both presented in the form of body writing, tables, and pictures. This section also contains a discussion of the results of the analysis, which contains an interpretation of the research results obtained and discussion associated with the results that have been reported. Avoid excessive use of graph if it can be presented in a short body writing. Number the pictures and tables in order. All images and tables presented should be placed in the body writing. Images in graphical form can be created using computer whose results are printed using either laser or quality inkjet printer.

This research was conducted by distributing questionnaires to 56 businesspeople in the culinary subsector of the creative economy. Characteristics of respondents are those who have a business in the creative economy of the culinary sub-sector and are affected by the occurrence of the COVID-19 pandemic as well as gender, age, and also the latest education of culinary businesses. Descriptive analysis results show that:

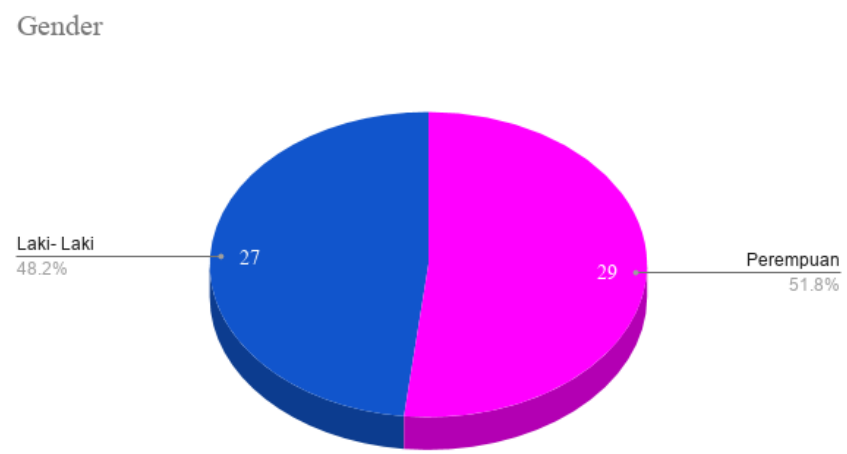

Fig 3:- Gender of respondents

Male respondents numbered 27, with a percentage of $48.2 \%$ of the respondents, and female respondents were more than two people, with a $51.8 \%$ percentage.

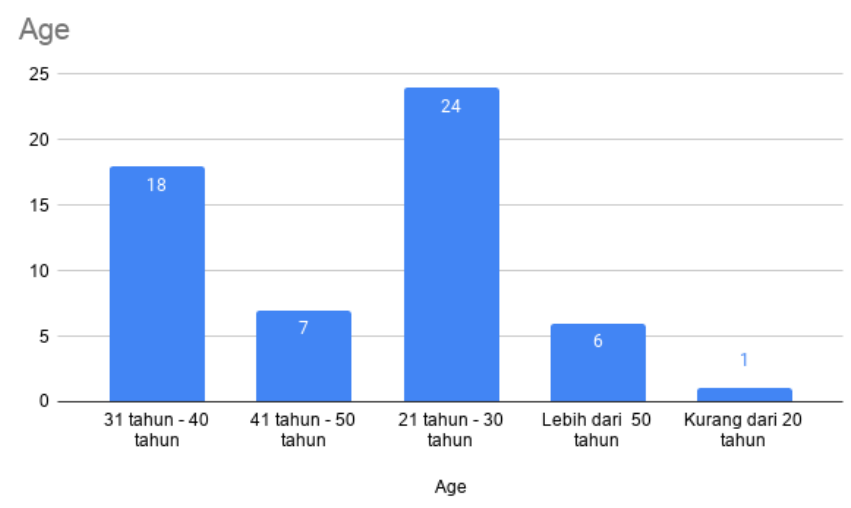

Fig 4:- Age of respondents

The age of most respondents, amounting to 24 people with ages 21-30, has a percentage of $42.8 \%$ of the respondents. Respondents aged 31-40 years had a percentage of $32.1 \%$, with a total of 18 people. Respondents aged 41-50 have a percentage of $12.5 \%$, with a total of 7 people. Respondents who are more than 50 years old have a percentage of $10.7 \%$, with a total of 6 people. The rest are respondents less than 20 years old, with a percentage of less than $2 \%$. 


\section{The Last Education}

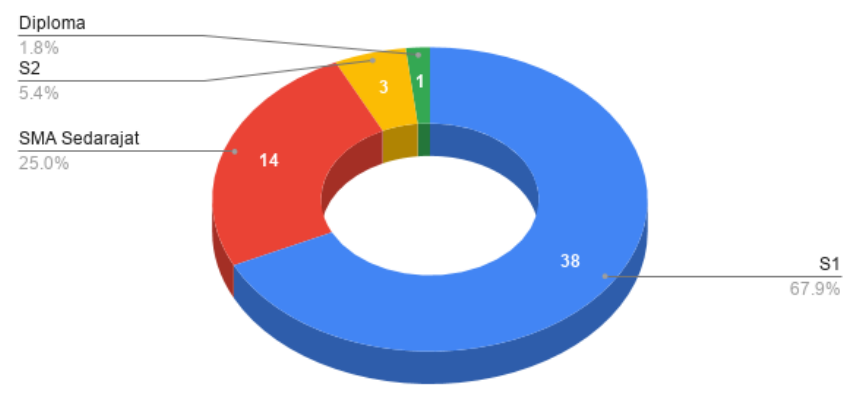

Fig 5:- Lastest education respondents

Besides, the majority of respondents had a bachelor's level of education, totaling 38 with a percentage of $67.9 \%$. The second most is with a high school education with a percentage of $25 \%$, totaling 14 people. Furthermore, the rest is with the last education of Masters and Diploma, with three people for Masters and 1 for the Diploma.

The questionnaire distributed consisted of 19 question items, which were divided into four variables: supplier variable $\left(\mathrm{X}_{1}\right)$, distribution channel $\left(\mathrm{X}_{2}\right)$, and competitive advantage $\left(\mathrm{X}_{3}\right)$ on business performance $(\mathrm{Y})$.

\section{A. Validity Test}

In this study, the validity test is done by comparing the value of $r$ arithmetic with $r$ table. If the calculated $r$-value is higher than the $r$ table value, the item in question is considered valid. The results of the validity test can be seen in table 1.

\begin{tabular}{|c|c|c|c|}
\hline Variable & $\mathrm{r}_{\text {count }}$ & $\mathrm{r}_{\text {table }}$ & Information \\
\hline Supplier $\left(\mathrm{X}_{1}\right)$ & $0,582-0,724$ & 0,3415 & Valid \\
\hline $\begin{array}{c}\text { Distribution } \\
\text { Channel }\left(\mathrm{X}_{2}\right)\end{array}$ & $0,650-0,837$ & 0,3415 & Valid \\
\hline $\begin{array}{c}\text { Competitive } \\
\text { Advantage }\left(\mathrm{X}_{3}\right)\end{array}$ & $0,464-0,879$ & 0,3415 & Valid \\
\hline $\begin{array}{c}\text { Performance } \\
(\mathrm{Y})\end{array}$ & $0,743-0,818$ & 0,3415 & Valid \\
\hline
\end{tabular}

Table 1:- The Result of Validity Test

Based on the table above, it can be seen that with a significance level of $5 \%$, the $\mathrm{r}$ table value of 0.3415 is obtained. The validity test for variable $\mathrm{X}_{1}$, which is a supplier variable, shows that the variable has a calculated $\mathrm{r}$ value of $0.582-0.724$, where the value is higher than the $r$ table value, so the variable $\mathrm{X}_{1}$ is considered valid. Validity test for variable $\mathrm{X}_{2}$, which is a distribution channel, shows that the variable has a calculated r-value of $0.650-0.837$, where the value is higher than the value of $r$ table, so the variable $\mathrm{X}_{2}$ is considered valid. $\mathrm{X}_{3}$, which is a competitive advantage, reflected that the variable has a calculated $r$ value of $0.464-0.879$, where the value is higher than the $r$ table value, so the $\mathrm{X}_{3}$ variable is considered valid. Likewise, the validity test for the $\mathrm{Y}$ variable, which is a businessperformance variable, has a calculated r-value of 0.743 -
0.818 , where the value is higher than the $r$ table value, so the $\mathrm{Y}$ variable is considered valid.

\section{B. Reliability Test}

The reliability test results based on Cronbach's Alpha formula can be seen in table 2 .

\begin{tabular}{|c|c|c|c|}
\hline Variable & $\begin{array}{c}\text { Reliability } \\
\text { Coefficient }\end{array}$ & $\begin{array}{c}\text { Critical } \\
\text { Point }\end{array}$ & Information \\
\hline Supplier $\left(\mathrm{X}_{1}\right)$ & 0,799 & 0,6 & Reliable \\
\hline $\begin{array}{c}\text { Distribution } \\
\text { Channel }\left(\mathrm{X}_{2}\right)\end{array}$ & 0,820 & 0,6 & Reliable \\
\hline $\begin{array}{c}\text { Competitive } \\
\text { Advantage }\left(\mathrm{X}_{3}\right)\end{array}$ & 0,623 & 0,6 & Reliable \\
\hline Performance $(\mathrm{Y})$ & 0,799 & 0,6 & Reliable \\
\hline
\end{tabular}

Table 2:- The Result of Reliability Test

Based on table 2, it can be seen that the supplier variables $\left(X_{1}\right)$, distribution channels $\left(X_{2}\right)$, competitive advantage $\left(\mathrm{X}_{3}\right)$, and business performance $(\mathrm{Y})$ have a score of an efficiency greater than 0.60 . The value of each variable is 0.799 for the supplier variable $\left(\mathrm{X}_{1}\right), 0.820$ for the distribution channel variable $\left(\mathrm{X}_{2}\right), 0.623$ for the competitive advantage variable $\left(\mathrm{X}_{3}\right)$, and 0.799 for the business performance variable $(\mathrm{Y})$. From these results, the three variables can be said to be reliable.

\section{Multiple Linear Regression Analysis}

The reliability test results based on Cronbach's Alpha formula can be seen in table 2 .

\begin{tabular}{|c|c|c|c|c|c|c|}
\hline \multicolumn{7}{|c|}{ Coefficients $^{\mathrm{a}}$} \\
\hline \multirow{2}{*}{\multicolumn{2}{|c|}{ Model }} & \multicolumn{2}{|c|}{$\begin{array}{c}\text { Unstandardized } \\
\text { Coefficients }\end{array}$} & \multirow{2}{*}{\begin{tabular}{|c|}
$\begin{array}{c}\text { Standardized } \\
\text { Coefficients }\end{array}$ \\
Beta \\
\end{tabular}} & \multirow[b]{2}{*}{$\mathrm{t}$} & \multirow[b]{2}{*}{ Sig. } \\
\hline & & B & $\begin{array}{l}\text { Std. } \\
\text { Error }\end{array}$ & & & \\
\hline \multirow[t]{4}{*}{1} & (Constant) & 5.107 & 3.214 & & 1.589 & .118 \\
\hline & Supplier & .509 & .106 & .530 & 4.822 & .000 \\
\hline & $\begin{array}{c}\text { Distribution } \\
\text { Channel }\end{array}$ & .087 & .099 & .099 & 2.875 & .386 \\
\hline & $\begin{array}{l}\text { Competitive } \\
\text { Advantage }\end{array}$ & .273 & .151 & .205 & 3.804 & .077 \\
\hline \multicolumn{3}{|c|}{$\begin{array}{c}\text { a. Dependent Variable: } \\
\text { Performance }\end{array}$} & & & & \\
\hline
\end{tabular}

Table 3:- The Result of Multiple Linier Regression Analysis

Based on table 3 can be written in the form of multiple linear regression equations as follows: $Y=5.107+4.822 X_{1}+2,875 X_{2}+3.804 X_{3}+e$

It can be seen that the work culture variable (X1) has a calculated $t$ value of 4,822 with a t table value of 2,007. It shows that the supplier variable (X1) has a significant influence on business performance because the $t$ value is higher than the $t$ table value. Meanwhile, the distribution channel variable (X2) has a calculated t value of 2,875 with a t table value of 2,007, which shows that the $\mathrm{X} 2$ variable has a significant effect on business performance because of 
the $\mathrm{t}$ value is higher than the $\mathrm{t}$ table value. Moreover, the variable of competitive advantage (X3) has a calculated $t$ value of 3,804 with a t table value of 2,007 , which shows that the variable $\mathrm{X} 3$ has a significant effect on business performance because the calculated $t$ value is higher than the $\mathrm{t}$ table value.

\begin{tabular}{|c|c|c|c|c|c|c|}
\hline \multicolumn{2}{|c|}{ Model } & $\begin{array}{c}\text { Sum of } \\
\text { Squares }\end{array}$ & df & $\begin{array}{c}\text { Mean } \\
\text { Square }\end{array}$ & F & Sig. \\
\hline \multirow{2}{*}{1} & Regression & 289.685 & 3 & 96.562 & 11.943 & $.000^{\mathrm{a}}$ \\
\cline { 2 - 8 } & Residual & 420.440 & 52 & 8.085 & & \\
\cline { 2 - 8 } & Total & 710.125 & 55 & & & \\
\hline
\end{tabular}

a. Predictors: (Constant), Supplier, Distribution Channel, Competitive Advantage

b. Dependent Variable: Performance

\section{Table 4:- ANOVA $^{\mathrm{b}}$}

Based on table 4, shows that the calculated $F$ value obtained is 11,943 , with a table $F$ value of 2.78 . It shows that supplier variables (X1), distribution channels (X2), and competitive advantage variables (X3) have a significant (simultaneous) effect on business performance variables because they have a calculated $F$ value higher than the $F$ table.

\begin{tabular}{|c|c|c|c|c|}
\hline \multicolumn{5}{|c|}{ Model Summary } \\
\hline Model & R & R Square & $\begin{array}{c}\text { Adjusted R } \\
\text { Square }\end{array}$ & $\begin{array}{c}\text { Std. Error of } \\
\text { the Estimate }\end{array}$ \\
\hline 1 & $.639^{\mathrm{a}}$ & .408 & .374 & 2.843 \\
\hline
\end{tabular}

a. Predictors: (Constant), Supplier, Distribution Channel, Competitive Advantage

Table 5:- The Result of the Coefficient of Determination

From table 5, we can get the coefficient of determination as follows:

$\mathrm{KD}=\mathrm{R}^{2} \times 100 \%$

$=(0.639)^{2} \times 100 \%$

$=40,8 \%$

Based on the above calculations it can be seen that the supplier variable $\left(\mathrm{X}_{1}\right)$, distribution channel $\left(\mathrm{X}_{2}\right)$, and competitive advantage $\left(\mathrm{X}_{3}\right)$ have a simultaneous influence of $40.8 \%$ on the variable business performance $(\mathrm{Y})$, while the remaining $59.2 \%$ is influenced by factors others that were not examined in this study.

\section{CONCLUSIONS}

Based on the results of research that has been done, several conclusions can be drawn, including:

$>$ There is a positive and significant influence on the supplier variable $\left(\mathrm{X}_{1}\right)$ on the business performance variable. It is evidenced by the acquisition of the calculated $\mathrm{t}$ value of 4.882 , which is higher than the $\mathrm{t}$ table value of 2007 .
There is a positive and significant influence on the distribution channel variable $\left(\mathrm{X}_{2}\right)$ on business performance variables. It is evidenced by the acquisition of the calculated $t$ value of 2.875 , which is higher than the $t$ table value of 2007 .

There is a positive and significant influence on the variable of competitive advantage $\left(\mathrm{X}_{3}\right)$ on business performance variables. It is evidenced by the acquisition of the calculated $t$ value of 3,804 , which is higher than the $t$ table value of 2007 .

$>$ There is a positive and significant simultaneous influence on supplier variables $\left(\mathrm{X}_{1}\right)$, distribution channels $\left(\mathrm{X}_{2}\right)$, and competitive advantage variables $\left(\mathrm{X}_{3}\right)$ on business performance variables. It is evidenced by the acquisition of the calculated $\mathrm{f}$ value of 11,943 , which is higher than the $t$ table value of 2.78 .

$>$ In the future, this research can still be very developed because the supplier variable $\left(\mathrm{X}_{1}\right)$, distribution channel $\left(\mathrm{X}_{2}\right)$, and competitive advantage variable $\left(\mathrm{X}_{3}\right)$ have a simultaneous influence of $40.8 \%$ on the business performance variable (Y). Because of this, there are still $59.2 \%$ of other factors that can be investigated.

\section{ACKNOWLEDGMENT}

This research was supported by Mercu Buana University. Furthermore, we thank Dr. Sugeng Santoso is a lecturer at Mercu Buna University and also serves as the Expert Staff of the Minister of Maritime Economics, the Coordinating Ministry for Maritime Affairs and Investment, which has inspired us to take up this topic.

\section{REFERENCES}

[1]. Basu, R., \& Wright, J. N. (2010). Total supply chain management. Elsevier.

[2]. Bekraf. (2017). Rencana Strategis Badan Ekonomi Kreatif 2015-2019. Jakarta: Badan Ekonmi Kreatif Indonesia.

[3]. International Monetary Fund. (2020). World Economic Outlock Chapter 1 The Great Lockdown, Washington, DC, United State.

[4]. Kemenkes RI. (2020). Protokol Komunikasi Publik COVID-19. Jakarta.

[5]. Kementerian Pariwisata dan Ekonomi Kreatif RI. (2014). Ekonomi Kreatif: Kekuatan Baru Indonesia Menuju 2025. Jakarta: RURU Corps.

[6]. Latifah, S. W., \& Syam, D. (2020). Pengembangan Indikator Penilaian Kinerja Penerapan Faktor Lingkungan Supply Chain Umkm. Jurnal Performance "Bisnis Dan Akuntansi," 10(1), 1-17.

[7]. Jogloabang. (2019). UU 24 tahun 2019 tentang Ekonomi Kreatif. Retrieved From https://www.jogloabang.com/pustaka/uu-24-2019ekonomi-kreatif

[8]. Lu, D. (2011). Fundamentals of supply chain management. Bookboon.

[9]. Maida, M.T., Riyanto, S., dan Ali, H. 2017. Effect of Job Satisfaction and Leadership Style Towards Employee Productivity at PT Asuransi Umum 
Bumiputera Muda 1967. Saudi Journal of Business and management Studies Vol-2 : 157-168.

[10]. Maychel, \& Purnomo, B. (2020). Pengaruh Promosi,Saluran Distribusi Dan Kualitas Pelayanan Terhadap Keputusan Pembelian Produk Valve PT Valmatic Indonesia.

[11]. Mello, A. D. (1997). The heart of the enlightened: a book of story meditations. Glasgow: Fount Paperbacks.

[12]. Mulyadi. 2001. Sistem Akuntansi Edisi Tiga. Jakarta :SalembaEmpat.

[13]. OECD. (2014). Tourism and the Creative Economy. OECD: Paris.

[14]. Pavitta, et.al. (2019). Culinary. Jakarta: Simpul Group.

[15]. Peraturan Gubernur DKI Jakarta. (2020). Pergub DKI Jakarta Nomor 47 Tahun 2020 tentang Pembatasan Kegiatan Berpergian Keluar dan/atau Masuk Provinsi Daerah Khusus Ibukota Jakarta Dalam Upaya Pencegahan Penyebaran Corona Virus Disease 2019 (Covid-19). Jakarta.

[16]. Peraturan Pemerintah. (2020). PP No.21 Tahun 2020 tentang Pembatasan Sosial Berskala Besar dalam Rangka Percepatan Penanganan COVID-19.

[17]. Riyanto, S., \& Lukertina. (2019). Does the Good Corporate Governance Culture Good for Workers? IOSR Journal of Business and Management (IOSRJBM), 21(8), 15-20. https://doi.org/10.9790/487X2108041520

[18]. Sadiyah, H \& Putra, Y.M (2017, September 27). Lima Kuliner ini Ditetapkan Sebagai Makanan Nasional. Retrieved From https://www.republika.co.id/berita/jurnalismewarga/wacana/12/04/13/gayahidup/kuliner/17/09/27/owxz06284-lima-kuliner-iniditetapkan-sebagai-makanan-nasional

[19]. Setyawati, A. (2015). Keunggulan Kompetitif dan Inovasi (Studi pada UMKM Sektor Industri Makanan dan Minuman di Bandung Raya. Akademika, 13(2), 41-44.

[20]. Swastha, Basu. (2007). Azas-Azas Marketing.Yogyakarta :Penerbit Liberty.

[21]. Tjiptono, F. (2008). Strategi Pemasaran. Yogyakarta: Penerbit Andi.

[22]. Wheelen, Thomas L dan Hungger, J. David, (1995). Strategic Management and Business Policy, Singapore, Addison Wessley.

[23]. Who.int. (2020). Coronavirus. Diakses pada 17 Mei 2020, dari https://www.who.int/healthtopics/coronavirus\#tab=tab_1

[24]. Who.int. (2020). Pertanyaan dan jawaban terkait Coronavirus. Diakses pada 18 Mei 2020, dari https://www.who.int/indonesia/news/novelcoronavirus/qa-for-public

[25]. Wisner, J. D., Tan, K.-C., \& Leong, G. K. (2012). Principles of Supply Chain Management, (Third Edit). Cengage Learning.

[26]. Zulher, Z., \& Norawati, S. (2019). Supply Chain Managemen Pengaruhnya Pada Kinerja Umkm Pada Sentra Pengolahan Hasil Perikanan Desa Koto Mesjid Kecamatan Kecamatan Xiii Koto Kamar. 